\title{
Efficiency of Water Use and Associated Characteristics of Lehmann Lovegrass
}

\section{NEAL WRIGHT AND A. K. DOBRENZ}

Highlight: Efficiency of water use of five lines and the cultivar 'A-68' of Lehmann lovegrass (Eragrostis lehmanniana Nees) was related to seedling drought tolerance and to physiological and morphological plant characteristics. Components of efficiency of water use (transpired water and dry matter produced) and the values of water-use efficiency (measured as the number of units of transpired water per unit of dry matter produced) varied among lines. Line L-38 was most efficient in water use (water-use efficiency value of 135), had the highest percentage of survival, 32.4\%, (seedling drouth tolerance) and produced the most dry matter (8.31g). The ratios of maximum recorder deflection of petroleum ether extract and the total area of optical deflection of petroleum ether extract to dry weight of leaves were variable among lines and significantly associated with efficiency of water use and seedling drouth tolerance. High deflection values were associated with high efficiency of water use and high percentage of survival. Stomate density was different among lines and was higher on the upper surface than on the lower surface of the leaf blade. Stomate density was not significantly associated with efficiency of water or seedling drouth tolerance.

The complex and unpredictable arid environments are most limiting to plant life during the early stages of germination, emergence, and seedling growth (Wright, 1971a). With improved genotypes for plant establishment and survival during early stages of growth, a primary concern is an understanding of plant characteristics which permit their performance under stress environments of aridity.

Water is a major component of an aridland environment that influences all plant growth during establishment, survival, and production of dry matter of rangeland grasses. Quantity and distribution of available water may limit plant growth under conditions of aridity. When moisture is restricted during the growing season, the efficient use of available water

The authors are research agronomist, Plant Science Research Division, Agricultural Research Service, U. S. Department of Agriculture and professor, Department of Agronomy and Plant Genetics, University of Arizona, Tucson.

The research is a result of the contribution from the Plant Science Research Division, Agr. Res. Serv., U. S. Dep. Agr., and the Department of Agronomy and Plant Genetics, University of Arizona, Tucson. This research was financed in part by Grant 716-15-2 from the Cooperative State Research Service, U. S. Department of Agriculture. (Arizona Agricultural Experiment Station Journal Paper No. 1849.)

Manuscript received March 16, 1972. determines the level of productivity. Genotypes improved for stand establishment and survival can be genetically manipulated for increased or decreased response for efficiency of water use.

\section{Lehmann lovegrass (Eragrostis} lehmanniana Nees) is a rangeland grass that has shown the capability of acceptable seedling establishment on desert grasslands of the Southwest for the past 35 years. Efficiency of water use of genotypes selected for superior stand establishment and survival ability (Wright and Brauen, 1971) may be greater, lesser, or the same as unselected types. The current investigation of Lehmann lovegrass was designed to study: (a) the efficiency of water use, (b) the relationship of seedling drouth tolerance and efficiency of water use, and (c) the association of transpired water, dry matter production, stomate density, and petroleum ether extract (plant waxes) determination with efficiency of water use and seedling drouth tolerance.

Miller and Hunt (1966) presented an extensive review of water requirements of crop plants and reported that efficiency of water use and drouth tolerance of rangeland grasses were not associated. They stated that several authors reported heritable variability among genotypes within species, suggesting the possibility of developing improved strains for efficient use of water. Efficiency of water use of weeping lovegrass (E. curvula (Schrad.) Nees) (Wright, 1971b) showed a negative association with seedling drouth tolerance in seedling and mature plants (Wright and Dobrenz, 1970). Weng and Quinones (1969) did not detect differences among strains of vine-mesquitegrass (Panicum obtusum H. B. K.) for efficiency of water use. They concluded that high production of dry matter could not be used to select for low water use of vine-mesquitegrass. A positive association has been reported between increased production of dry matter and higher water use of three perennial grasses (Mathias et al. 1971).

A comprehensive review of plant waxes was presented by Kolattukudy (1970) and Wettstein-Knowles (1970). Kolattukudy stated that plant surfaces are covered with a complex mixture of lipids, which are called plant waxes. He concluded that the primary function of such wax was to protect the plant from excess water loss through transpiration and other hazards of stress environments.

Stomate densily of blue panicgrass (Panicum antidotale Retz.) varied with age of leaf blade. Differences of stomate density were not found (Dobrenz et al., 1969) between the base, middle, and tip of individual leaves, while the lower leaf surface had significantly higher stomate density than the upper leaf surface of the same leaf blade. Stomate density and efficiency of water use were not associated. However, low stomate density was significantly associated with drought tolerance of blue panicgrass.

\section{Materials and Methods}

Performance for seedling drouth tolerance of Lehmann lovegrass lines was investigated by Wright and Brauen (1971). They reported mean survival percentages of $32.4,30.2,27.3,20.1,6.0$, and 2.5 for lines L-28, L-38, L-19, A-68, L-24, and L-4, respectively. These six lines, including the cultivar 'A-68', were chosen to represent the extremes of seedling drouth tolerances.

Single plants of uniform genotypes from apomictic seed were established in plastic containers (4.2 liter) with a hole for size zero rubber stopper at the base of the container for drainage during plant establishment. Screened pea gravel was placed in the container to bring the weight of the container, cork, and gravel to $500 \mathrm{~g}$. Containers were filled with $2,000 \mathrm{~g}$ of a soil mixture. The mixture by 
volume was 3 parts of sandy clay loam soil and 1 part peat moss with $100 \mathrm{~g}$ organic fertilizer and $3 \mathrm{~g}$ sulfur added per $20 \mathrm{~kg}$ of the soil mixture. Plants were grown in the greenhouse, where temperatures ranged from $32^{\circ} \mathrm{C}$ maximum and $20^{\circ} \mathrm{C}$ minimum with $40 \%$ average relative humidity. The statistical design was a randomized complete block of 16 containers of each line with 4 replications of 4 subsamples of each line.

When plants of each line were three weeks old, the soil was covered with $11 \mathrm{~g}$ of coarse styrofoam to reduce evaporation from the soil surface. Rubber stoppers were placed in the drainage hole of the containers and a wire support $(70 \mathrm{~g})$ was inserted in each container to support the developing stems and leaves. Water was added to bring the soil moisture to field capacity. Total weight of each container was $3,120 \mathrm{~g}$ (500 $\mathrm{g}$ for container, rubber stopper, and gravel; 2,000 $\mathrm{g}$ of soil; $70 \mathrm{~g}$ for wire support; $11 \mathrm{~g}$ of styrofoam; and $539 \mathrm{~g}$ of water). Containers were weighed daily, and when soil moisture was depleted to $50 \%$ of field capacity, water was added to return each container to its original weight $(3,120 \mathrm{~g})$.

When all plants had produced a flowering inflorescence, leaf impressions were obtained to determine density of stomate. The silicone rubber technique (Sampson, 1961) was used to take impressions from the upper and lower leafblade surfaces. Impressions were made of two leaf blades of one plant (subsample) of each line chosen at random from each replication. Five microscope fields of each impression were chosen at random, and the number of stomates were counted. Magnification was 200X, and the surface area was $0.6 \mathrm{~mm}^{2}$ per microscope field.

Petroleum ether extract determinations were obtained from one plant (subsample) of each line chosen at random from each replication. Three leaf blades were removed from each plant and placed in petroleum ether for 2.5 hours. The extract was diluted with 2 parts ethanol to 1 part extract. The solutions were assayed spectrophometrically, and the optical density of a specific wave length (274 $\mathrm{nm}$ ) was determined. Maximum recorder deflection and total area of optical deflection of the petroleum ether extract of each line were recorded.

Individual plants (subsamples) were harvested at the end of 25 days in three components: dry matter above $15 \mathrm{~cm}$, dry matter from 0 to $15 \mathrm{~cm}$, and roots. The plant parts were dried at $80^{\circ} \mathrm{C}$ and weighed.

The grams of water added during the study, minus the grams evaporated from check containers covered with styrofoam without a plant, were used to calculate the amount of water transpired by each plant.

Water-use efficiency values were calculated as the number of units of transpired water per unit of dry matter produced. Calculations were made on an individual plant basis; data presented are means of measurements of 16 plants of each line.

\section{Results and Discussion}

Dry-matter production of the three components of harvest showed the same relationship among lines. Since the amount of transpired water was the same for separate or combined components of dry matter produced, the total dry matter of the plant was used to determine efficiency of water use values (Table 1). The two components of efficiency of water use, transpired water and dry matter produced, varied significantly among lines. Lines with highest production of dry matter transpired the most water $\left(r=91^{* *}\right)$. Significant values of correlation coefficient ( $r$-values) are .40 at the $5 \%$ level and .52 at the $1 \%$ level of probability. Efficiency of water use was not significantly associated with transpired water $(r=-.32)$, while efficiency was significantly associated with produc. tion of dry matter $\left(r=-.65^{* *}\right)$. Neither individual measurement provided an accurate estimate of efficiency of water use, yet the efficiency of water use values demonstrated the interrelationship of transpired water and dry matter production. Lines of Lehmann lovegrass (Table 1) were relatively efficient (low values) when compared with efficiency of water use of other plants (Miller and Hunt, 1966). The most-efficient lines (L-38 and L-28) produced twice the dry matter of the least-efficient lines (L-4 and L-24). The desired performance would be minimum water used with maximum production, which would result in superior efficiency of water use (low values).

High drouth survival was associated with minimum water used per unit of dry matter produced. That is, seedling drouth tolerance was positively associated with efficiency of water use $\left(r=-.95^{* *}\right)$. In contrast, a significant negative association was found between seedling drouth tolerance and efficiency of water use of weeping lovegrass (Wright and Dobrenz, 1970).

The negative and positive correlations between seedling drouth tolerance and efficiency of water use of the two lovegrass species may be related to the rela tive degree of tolerance to drouth. That is, the comparatively greater seedling drought tolerance of Lehmann lovegrass may provide the mechanism for positive association with efficiency of water use.

Stomate densities varied among lines (Table 1). Density was higher on the upper surface than on the lower surface of the leaf blade of all Lehmann lovegrass lines, which was the opposite of the findings for blue panicgrass (Dobrenz et al., 1969). Stomatal density was not associated with efficiency of water use. Seedling drouth tolerant lines L-38 and L-28 had low stomatal density on the top leaf surface. However, stomatal density did not lead to a firm conclusion of

Table 1. Survival percentage, transpired water $(\mathrm{g})$, dry matter production $(\mathrm{g})$, efficiency of water use, stomate density (no./mm ${ }^{2}$ ) and petroleum ether extract analysis of Lehmann lovegrass (Eragrost is lehmanniana Nees) lines.

\begin{tabular}{|c|c|c|c|c|c|c|c|c|c|}
\hline \multirow{2}{*}{$\begin{array}{l}\text { Line } \\
\text { no. }\end{array}$} & \multirow{2}{*}{$\begin{array}{c}\text { Survival } \\
\text { percentage }^{1}\end{array}$} & \multirow{2}{*}{$\begin{array}{c}\text { Transpired } \\
\text { water }\end{array}$} & \multirow{2}{*}{$\begin{array}{c}\text { Dry } \\
\text { matter }\end{array}$} & \multirow{2}{*}{$\begin{array}{l}\text { Water use } \\
\text { efficiency }\end{array}$} & \multicolumn{3}{|c|}{ Leaf-blade stomate } & \multicolumn{2}{|c|}{$\begin{array}{l}\text { Petroleum ether } \\
\text { exact ratios }\end{array}$} \\
\hline & & & & & Upper & Lower & Mean & OD/DW & $\mathrm{A} / \mathrm{DW}$ \\
\hline $\mathrm{L}-38$ & $32.4 \mathrm{a}^{3}$ & $1078 \mathrm{a}^{3}$ & $8.31 \mathrm{a}^{3}$ & $135 \mathrm{a}^{3}$ & 173 & 98 & $135 b^{3}$ & 7.47 & 323 \\
\hline L-28 & $30.2 \mathrm{ab}$ & $862 b$ & $6.41 \mathrm{~b}$ & $139 a$ & 138 & 96 & $117 \mathrm{a}$ & 8.04 & 331 \\
\hline L-19 & $27.3 \mathrm{a}-\mathrm{c}$ & $654 \mathrm{c}$ & $4.34 \mathrm{c}$ & $150 \mathrm{ab}$ & 198 & 138 & $168 \mathrm{~d}$ & 2.41 & 100 \\
\hline A- 68 & $20.9 \mathrm{~b}-\mathrm{g}$ & $1188 \mathrm{a}$ & $7.23 \mathrm{ab}$ & $163 \mathrm{ab}$ & 149 & 124 & $137 b$ & 0.21 & 21 \\
\hline L-24 & $6.0 \mathrm{kl}$ & $645 \mathrm{c}$ & $3.83 \mathrm{c}$ & $170 \mathrm{bc}$ & 193 & 98 & $146 \mathrm{c}$ & 0.90 & 59 \\
\hline $\mathrm{L}-4$ & 2.51 & $768 \mathrm{bc}$ & $4.42 \mathrm{c}$ & $178 \mathrm{c}$ & 149 & 78 & $114 \mathrm{a}$ & 2.91 & 136 \\
\hline
\end{tabular}

\footnotetext{
${ }^{1}$ From Wright and Brauen, 1971.

${ }^{2}$ Ratio (OD/DW) was maximum optical density of petroleum ether extract at $274 \mathrm{~nm}$ to dry weight (g) of leaves; and ratio (A/DW) was area of optical density curve $\left(\mathrm{cm}^{2}\right)$ to dry weight $(\mathrm{g})$ of leaves.

${ }^{3}$ Means within columns followed by the same letter were not significantly different at the $1 \%$ level of probability (Duncan's new multiple range test).
} 
relationship with efficiency of water use or seedling drouth tolerance.

The ratio of the maximum recorder deflection of the petroleum ether extract at $274 \mathrm{~nm}$ to dry weight of leaves (g) showed a wide range of values (Table 1). Lines L-38 and L-28, which were efficient for water use and seedling drouth tolerance, showed higher optical density ratios than the inefficient and drouth susceptible lines (L-4 and L-24). Efficiency of water use and maximum optical density ratios were associated $\left(r=-.79^{* *}\right)$. The significantly negative $r$-value indicated that the most efficient lines (low values) were associated with high deflection values of petroleum ether extract. A significant association was found between seedling drouth tolerance and high deflection of petroleum ether extract $\left(r=.63^{* *}\right)$.

The ratio of the area $\left(\mathrm{cm}^{2}\right)$ of optical deflection of petroleum ether extract to dry weight $(\mathrm{g})$ of leaves varied among lines and was similar in response to maximum recorder deflection (Table 1). Efficiency of water use and area of optical deflection of petroleum ether extract were associated $(r=-.77 * *)$. A significant association was found between seedling drouth tolerance and area of deflection of petroleum ether extract $\left(r=.60^{* *}\right)$. The shape of the curve was similar among selections, and the area was proportional to the maximum optical deflection. In general, the findings suggested that the relationship of petroleum ether extract with efficiency of water use and with seedling drouth tolerance of Lehmann lovegrass may prove to be a potential area of research and an important selection criterion.

\section{Literature Cited}

Dobrenz, A.K., L.N. Wright, A.B. Humphrey, M.A. Massengale, and W.R. Kneebone. 1969. Stomate density and its relationship to water-use efficiency of blue panicgrass (Panicum antidotale Retz.). Crop Sci. 9:354-357.

Kolattukudy, P.E. 1970. Plant waxes. Lipids 5:259-275.

Mathias, E.L., O.L. Bennett, G.A. Jung, and P.E. Lundberg. 1971. Effect of two growthregulating chemicals on yield and water use of three perennial grasses. Agron. J. 63:480483.

Miller, D.G., and O.J. Hunt. 1966. Water requirement of plants and its importance to grassland agriculture. Wyoming Agr. Exp. Sta. Res. J. 3. 11 p.

Sampson, J. 1961. A method of replicating dry or moist surfaces for examination by light microscopy. Nature 191:932-933.

Weng, V.K., and F.A. Quinones. 1969. Water requirement in strains of vine-mesquite (Panicum obtusum H. B. K.). Crop Sci. 9:412-415.
Wettstein-Knowles, P. von. 1970. The molecular phenotypes of the Eceriferum mutants, p. 146-193. In Barley genetics II. 2nd Int. Barley Genet. Symp., Pullman, Wash.

Wright, L.N. 1971a. Drought influence on germination and seedling emergence, $p$. 1944. In Drought injury and resistance in crops. Crop Sci. Soc. Amer., Spec. Pub. No. 2. $88 \mathrm{p}$.
Wright, L.N. 1971b. Registration of Catalina weeping lovegrass. Crop Sci. 11:

Wright, L.N., and S.E. Brauen. 1971. Artificial selection for seedling drouth tolerance and association of plant characteristics of Lehmann lovegrass. Crop Sci. 11:324-326.

Wright, L.N., and A.K. Dobrenz. 1970. Efficiency of water use and seedling drouth tolerance of Boer lovegrass, Eragrostis curvula Nees. Crop Sci. 10:1-2.

\section{回回回}

\section{Prairie Sandreed}

\section{(Calamovilfa longifolia): Water Infiltration and Use}

\section{J. KRISTIAN AASE AND J. ROSS WIGHT}

Highlight: Prairie sandreed (Calamovilfa longifolia) near Sidney, Mont., grows on rangeland in colonies ranging from 1 to $8 \mathrm{~m}$ in diameter. There were small differences in soil texture between prairie sandreed colonies and surrounding vegetation. Increased plant growth and residue accounted for higher water infiltration rates within the prairie sandreed colonies than on surrounding vegetation. Prairie sandreed used slightly more water, but the water-use efficiency was nearly twice that of the surrounding vegetation.

Prairie sandreed (Calamovilfa longifolia) grows on sandy prairie soils throughout the north and central Great Plains. It is a tall, coarse, tough, perennial, warm-season grass with large, spreading rhizomes. Near Sidney, Mont., it grows on soils of medium to coarse texture in colonies ranging from about 1 $\mathrm{m}$ to $8 \mathrm{~m}$ in diameter. It grows in nearly pure stands, resulting in distinct boundaries between prairie sandreed colonies and surrounding vegetation.

Prairie sandreed is a high producer and can be an important forage species. It is utilized extensively in summer and winter grazing systems (Forest Service, 1937; Phillips Petroleum Company, 1963;

The authors are soil scientist and range scientist, U. S. Department of Agriculture, Sidney, Montana.

The research is a contribution from the Northern Plains Branch, Soil and Water Conservation Research Division, Agricultural Research Service, U. S. Dep. Agr., in cooperation with the Montana Agricultural Experiment with the Montana Agricultural
Station. (Journal Series No. 330.)

Manuscript received February 9, 1972.
Welch, 1968). On the site studied, prairie sandreed disappears under high grazing intensities and is considered a "decreaser" under the Soil Conservation Service range condition classification system (Soil Conservation Service, 1971b).

Because of the distinct growth pattern of prairie sandreed, we investigated possible differences from the adjacent mixed prairie vegetation, particularly in soil profile and texture and water infiltration and water-use patterns.

\section{Study Area and Procedure}

The study area was located $2.5 \mathrm{~km}$ northwest of Sidney, Mont. $\left(47.45^{\circ} \mathrm{N}\right.$ and $104.10^{\circ} \mathrm{W}$ ), on a $2 \%$ east slope of rolling glacial-till upland. Site elevation was $600 \mathrm{~m}$. The climate is continental, and annual precipitation averages $33 \mathrm{~cm}$ with $80 \%$ falling during the growing season (April-September).

The soil (Williams loam) is classified as fine-loamy, mixed family of Typic Argiborolls formed on a thin loamy mantle over glacial till. The soil is well drained with no evidence of salt or alkali. 